\title{
月兄年十・二治 明
}

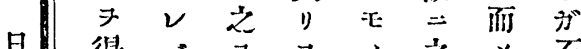

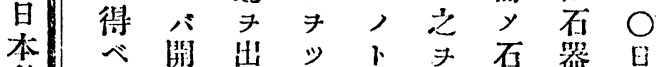

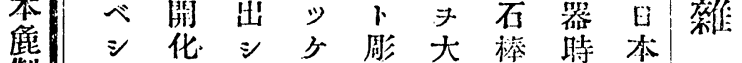

製侕稍後口刻别此代能

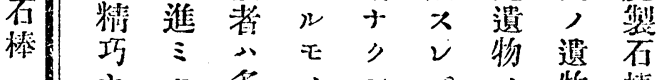

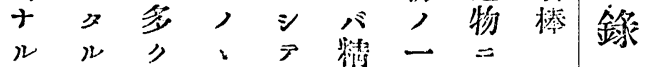

不 八諸三櫵巧部富

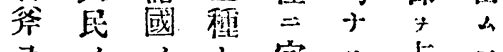

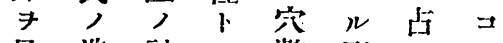

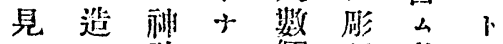

デ社大個刻基入

啳 $シ=77 \%$ 稚网

$=$ E 祭 得 学 兩数 外

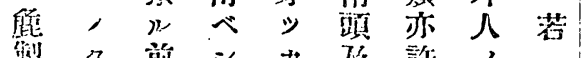

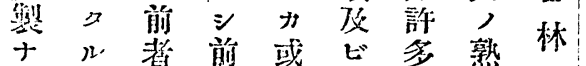

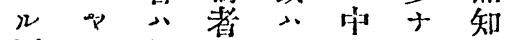

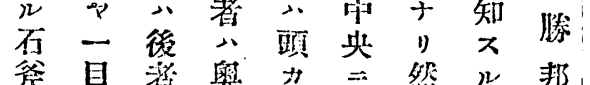

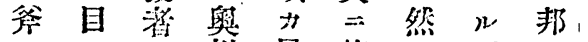

\#先小店数 $\exists$ 埋 大 $=$ 衣相生 闬葬江混食食計

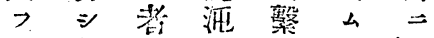
大彼〉無命, 便 ルノレ留ノ唒十 モ大バト諸㷳り

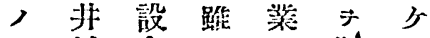
下村命比 7 IH 2 篇 二祭綿扶 シ 소 大 任祀夏 与 賴 酷

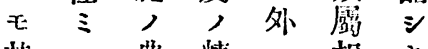

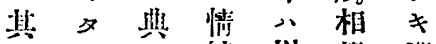

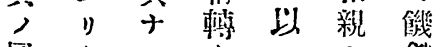

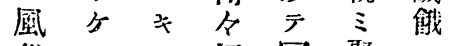
俗出切冠聚云 食之十故虞陷 巡人

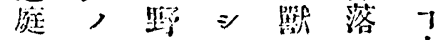
ア 民二ャノテ少

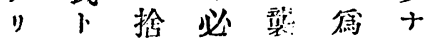
シ

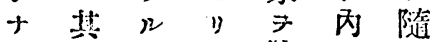

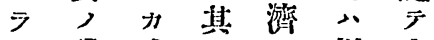
$\because$ 酯或, $\rightarrow$ 以

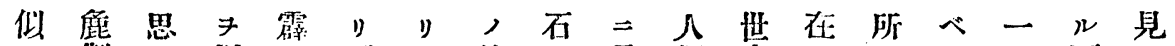

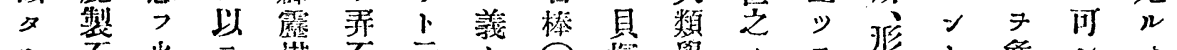

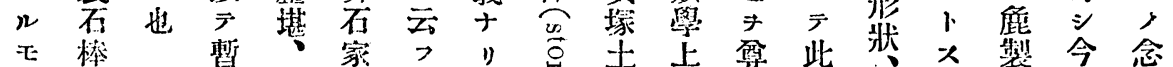

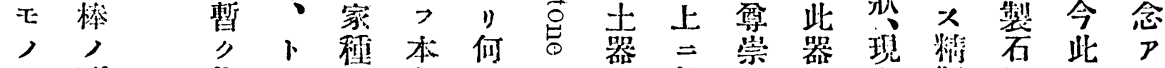
$>$ 排呼了邦、总塚於沙, 存製棒三》 レ状名ブ, 和

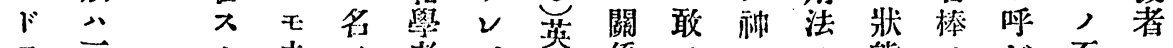

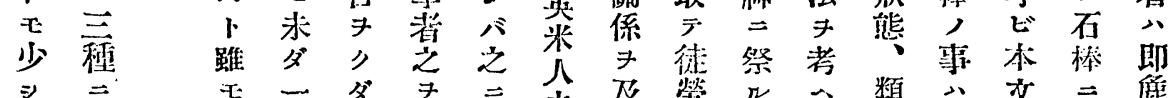

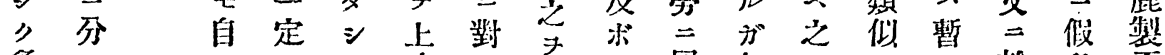

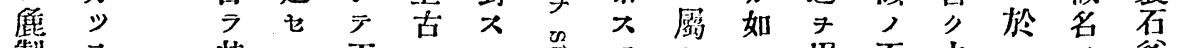

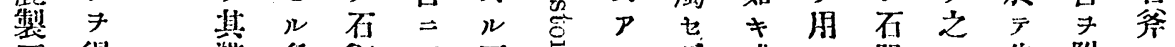

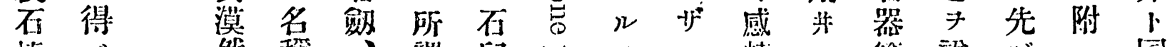
三ل 棒 五類他舀余雷亏見览市

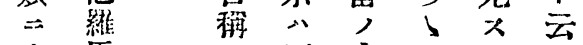

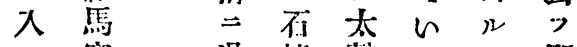

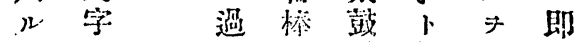
ベう少ノ假 以

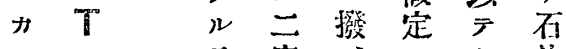
シ 原類 此 ズ製 $キ$ 代 况因了較今石精三

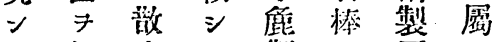

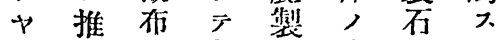

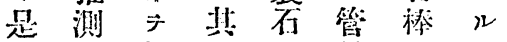
$F$ 大知古㰇光卜七

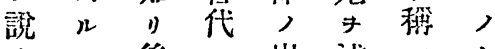
$\overline{7}=$ 子字、字子杵 " 小谽 


\begin{tabular}{|c|c|c|c|c|c|c|c|c|c|c|c|c|c|c|c|c|}
\hline 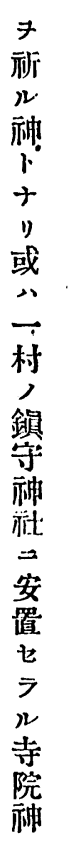 & 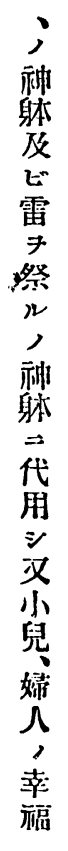 & 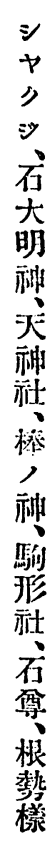 & 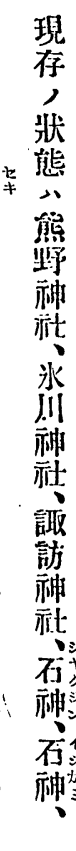 & 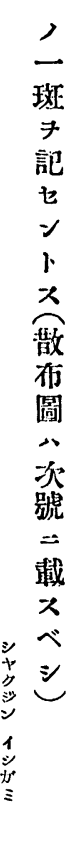 & 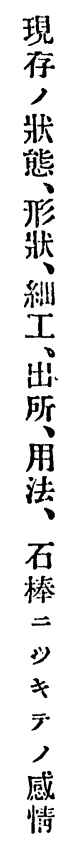 & 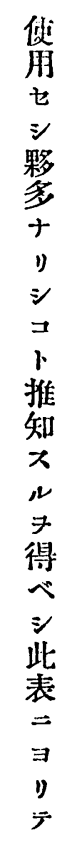 & 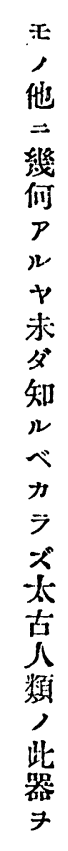 & 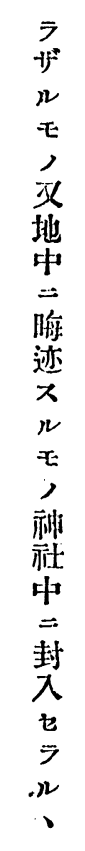 & 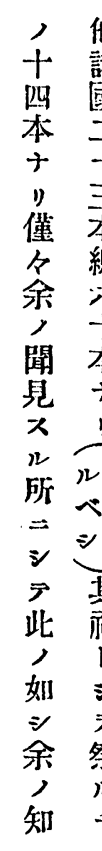 & 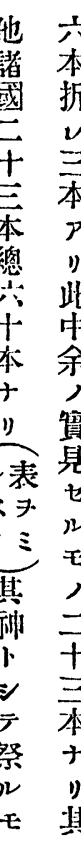 & 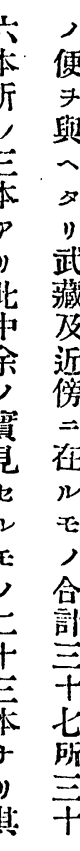 & 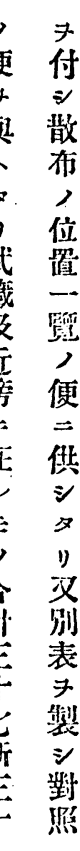 & 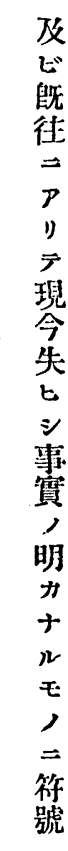 & 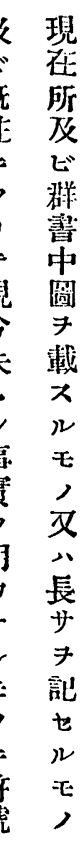 & 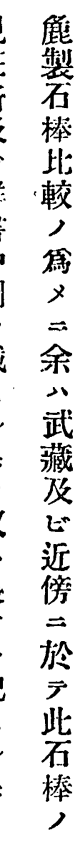 & 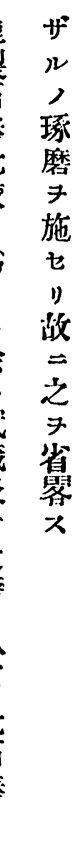 \\
\hline 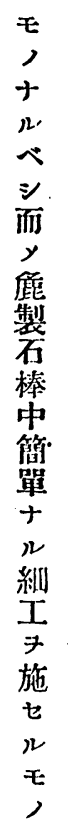 & 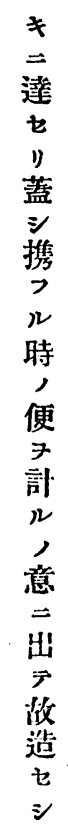 & 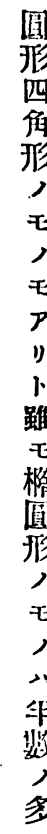 & 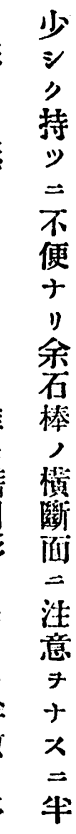 & 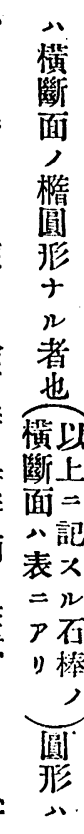 & 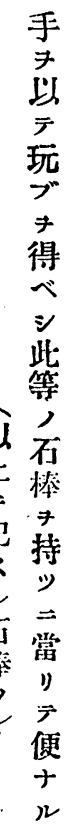 & 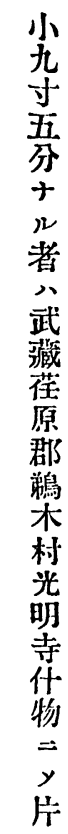 & 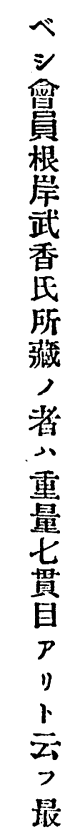 & 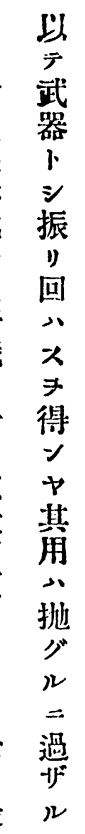 & 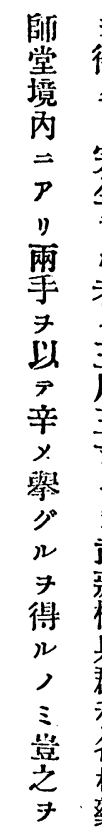 & 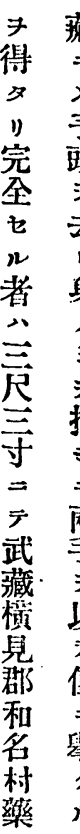 & 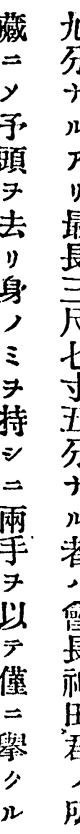 & 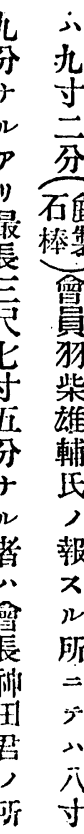 & 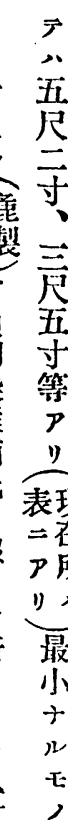 & 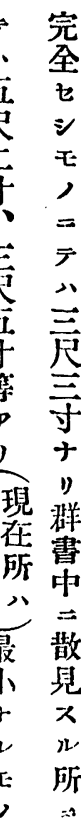 & 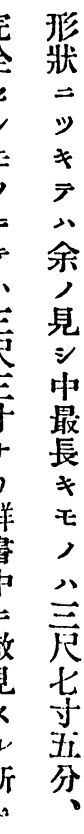 & 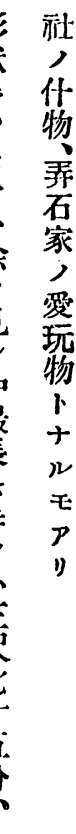 \\
\hline
\end{tabular}


月九年 $十$ 二治 明

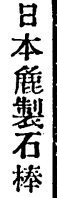

$\approx 1$.

总 囉

(保)

(4)

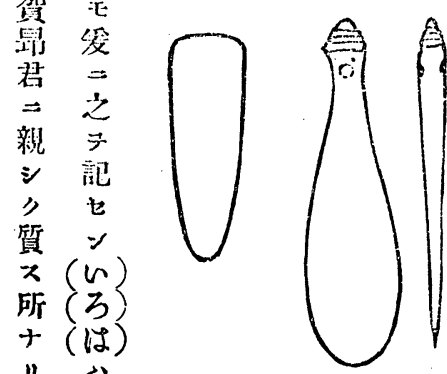

(n) 先

(ろ) $\neq$ 未 a 器接 法 川二ダ 2 骨 $=\exists$

木南充固器不㵷

製洋分 $\exists \exists$ 棒

$=\exists$, リ諸 $=ル$

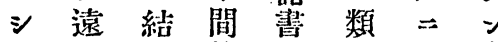

二航 果掕 $三$

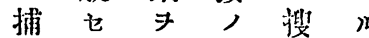

得 7 甞 石 先 棒

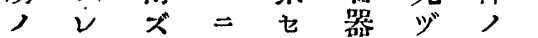

棒 》石其 U

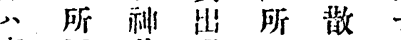

蒐以井现

政士村) 具

中り, 状 球

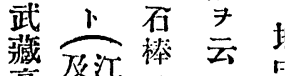

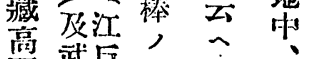

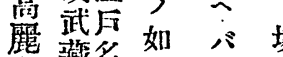

郡监名所

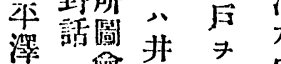

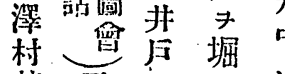

㷊文 $\neq$ 学 河

笛篔掘得

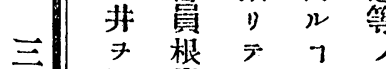

二 堀 殿 待 》㯊タり々 平香り武,

解 是藏 笏

$\exists$ 所 村 北 所

リ藏名訾 †

一,

文石基郡比 (it)

(3)

(b) 此駽五 $>$ 或心 小形分”叶 桇社 $卜$ (二) 横 央
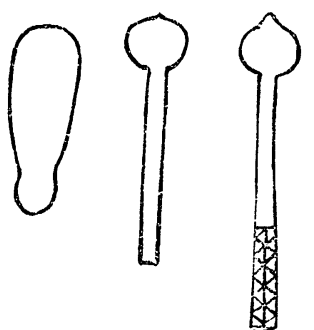

或 $\Rightarrow P$ 川 $=$

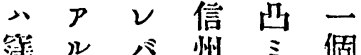
三七 楕 電 7 *人圆桪紧究 附二开教少 七シ十 ヨ穿

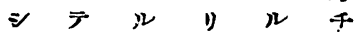
八坪 ベ出 $>$ 或 用井 $\approx$ 》 》

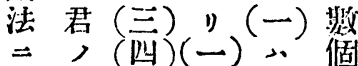
ラ 便實 心 武 利見下附藏連 然十七總言入

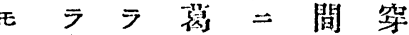
此 $シ 2$ 飾幅 郡 $\bar{\gamma}$

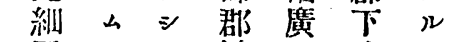

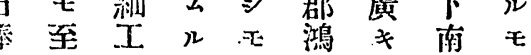
ノ $邓$, , 焉所烟, 形、゙ル洲十近济村? $\forall$ 状此飞杢り㑽示 $=$ り 
號九十第誌雑會學類人京東

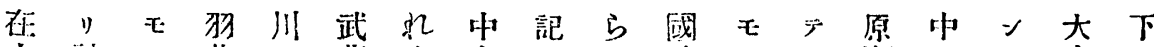

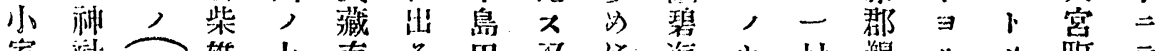

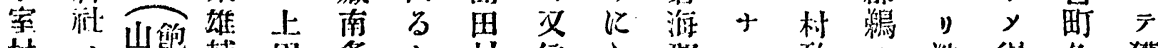

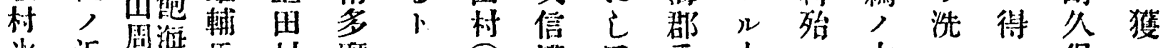

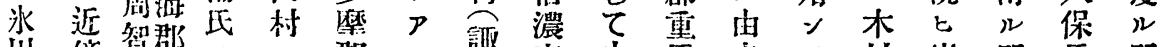
川傍貿郡, 三郡》詪奇少原寺に゙村出所氏 所

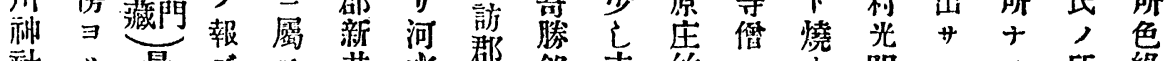

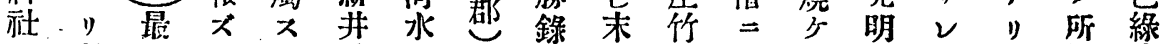
人發上次村中雷 社掘川所堭石革、雨霹ひ, 与次, 記方云

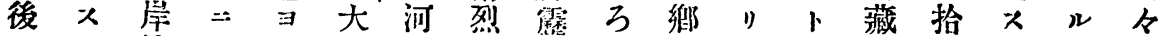

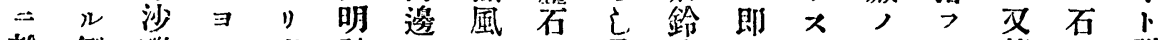

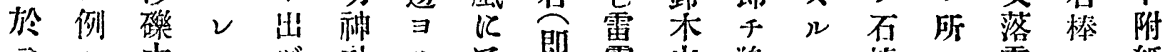

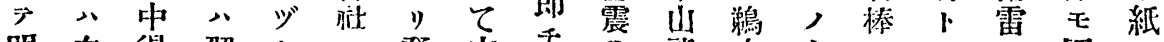

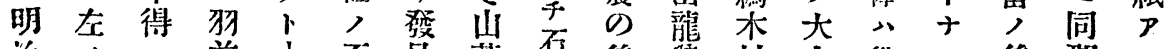

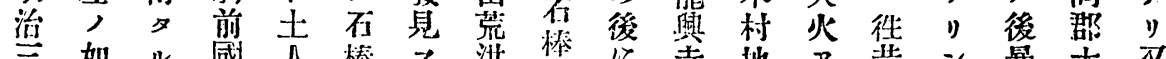

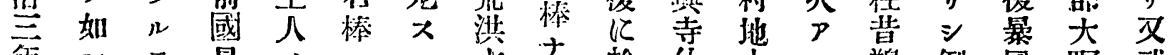

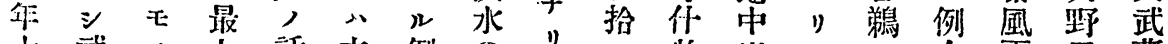

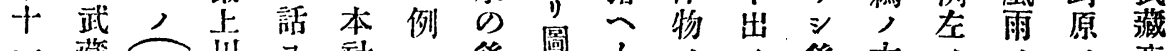

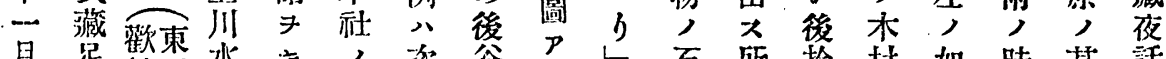
月足性丒水方, 次谷 士 市院川虫

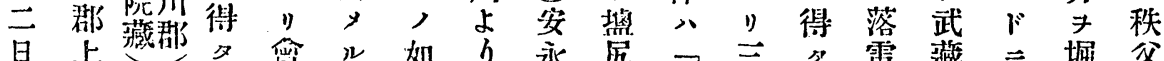

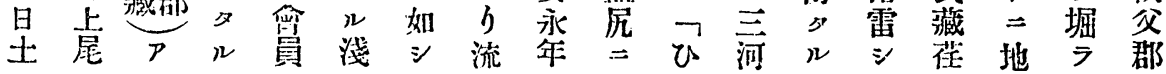

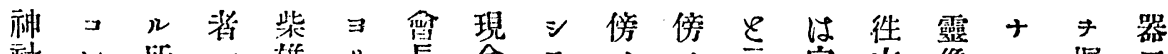

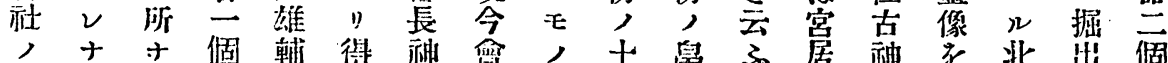

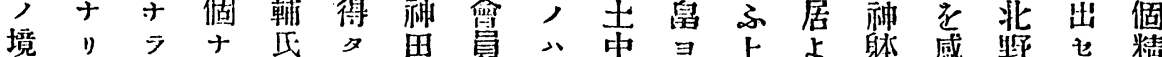

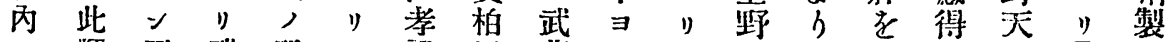

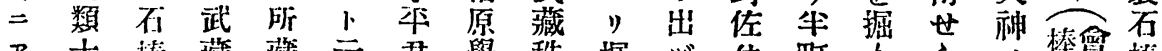

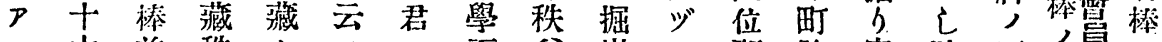

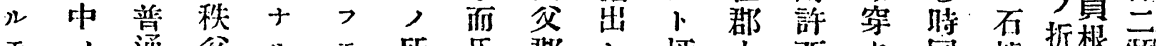

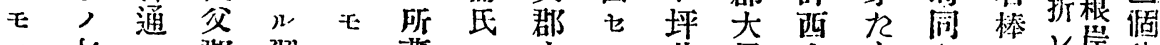

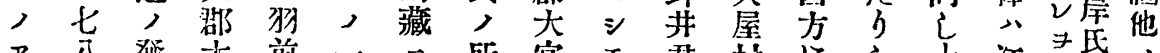

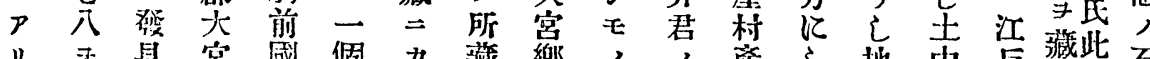

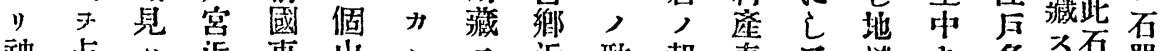
神占 身允偶傍思中江踥傍奇道社中封 万所武四 $卜$ 或 然 $\Rightarrow 川 \exists$ 川

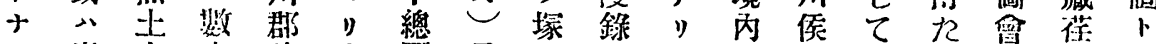

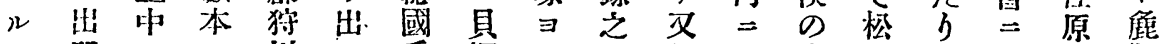
ア 所 $コ$ 円

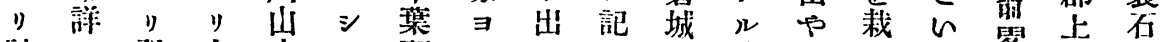

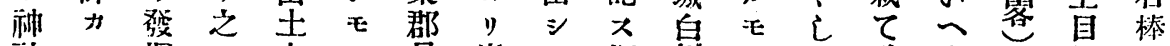

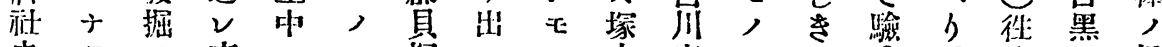
寺 院 ズル山り會利氏

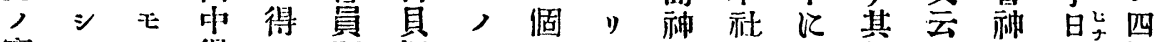

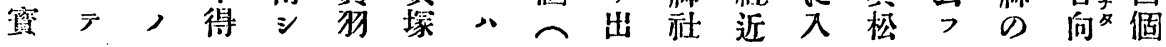




\section{月九年 $十$ 三治明}

日

本

魔自

製

石

八水作器 入崎石 $=$ 石本, 次轉ビ所

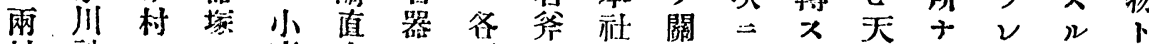
村神 $=>$ 高方 $シ$ 石 $；$ 係武ル變

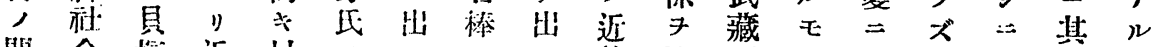

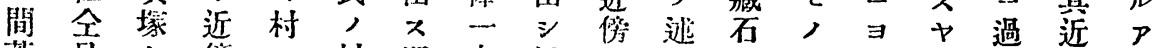

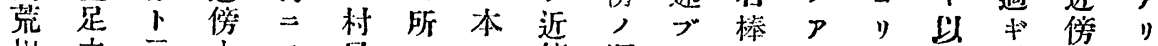

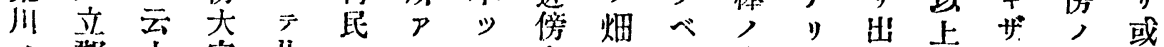

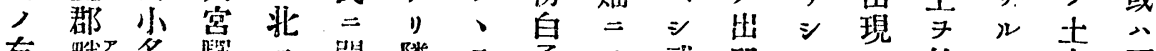

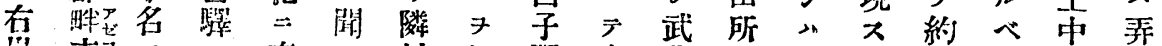

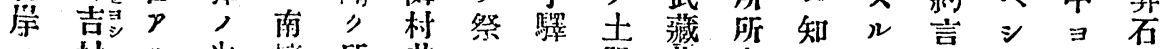

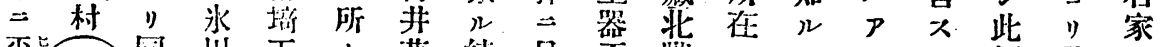

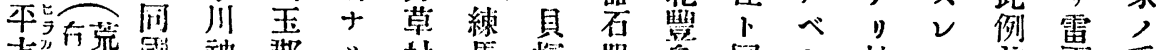

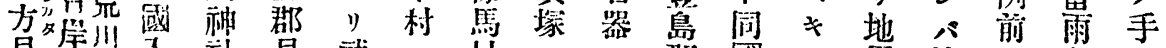

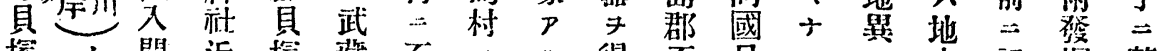

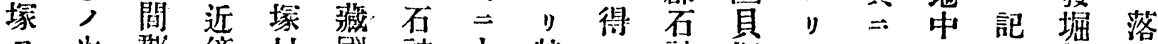
$P$ 水郡傍 村 或 神土特 ベ神塚

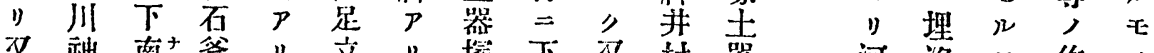

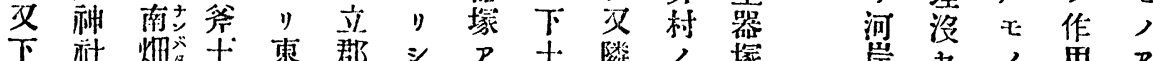

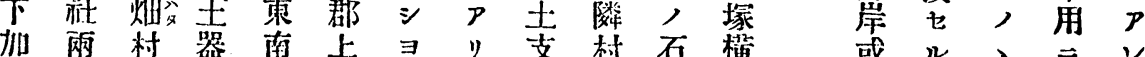

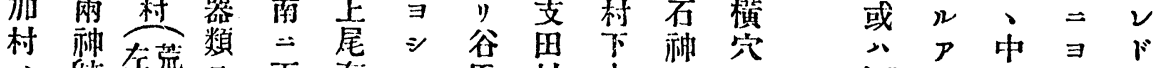

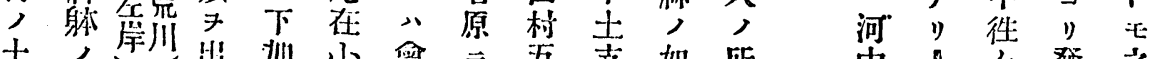
器石士 㴍溙心深士村山器基村心卜

$=$ 工見 見 移灭少要

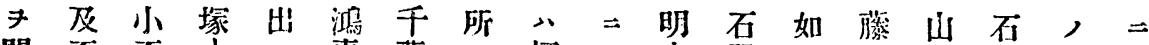

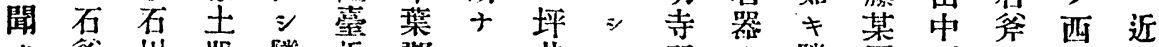

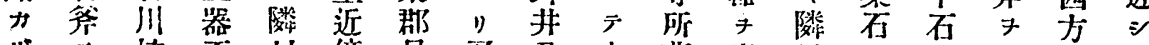
牧 7 植 石 村傍具齐君上藏出村棒器出 $\exists$ 武

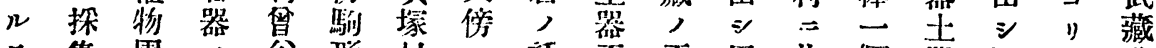
7 集 園人 谷形村三話石石甲 北個器駉出荏 疑 七 $\Rightarrow$ 出村社, 大

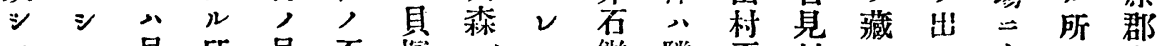
$=$ 具所具石㳟

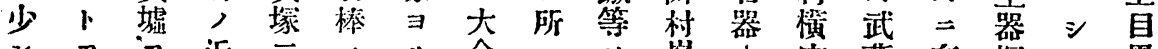

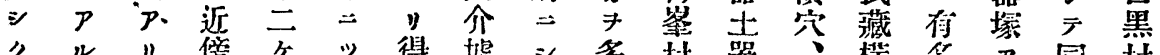

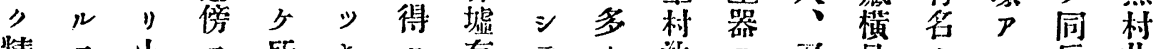
精 $=$ 小 $=$ 所

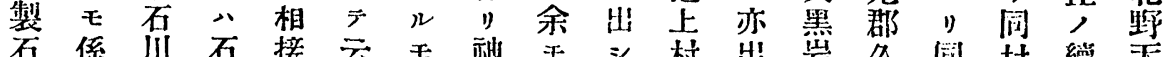

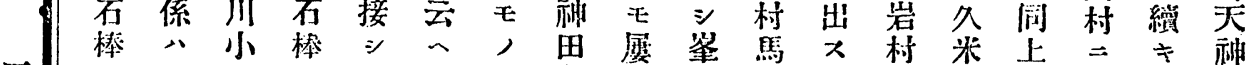

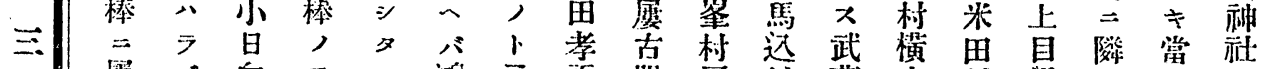

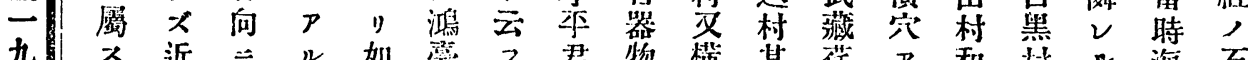

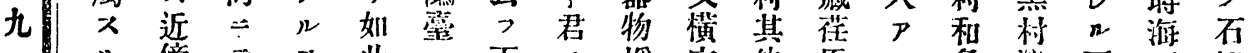

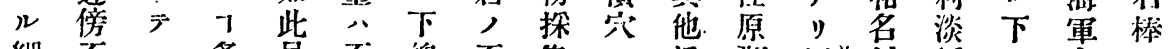

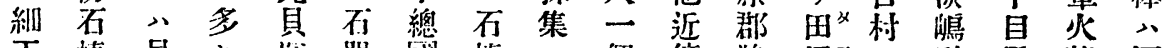

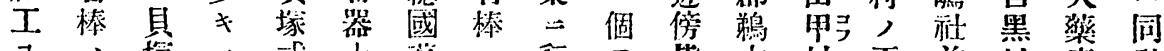

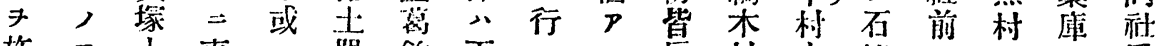

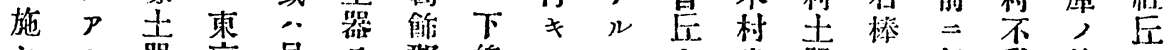

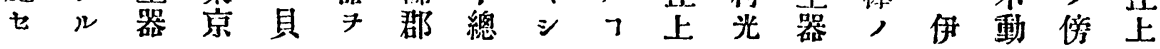


號九十第誌雊會學類八京東

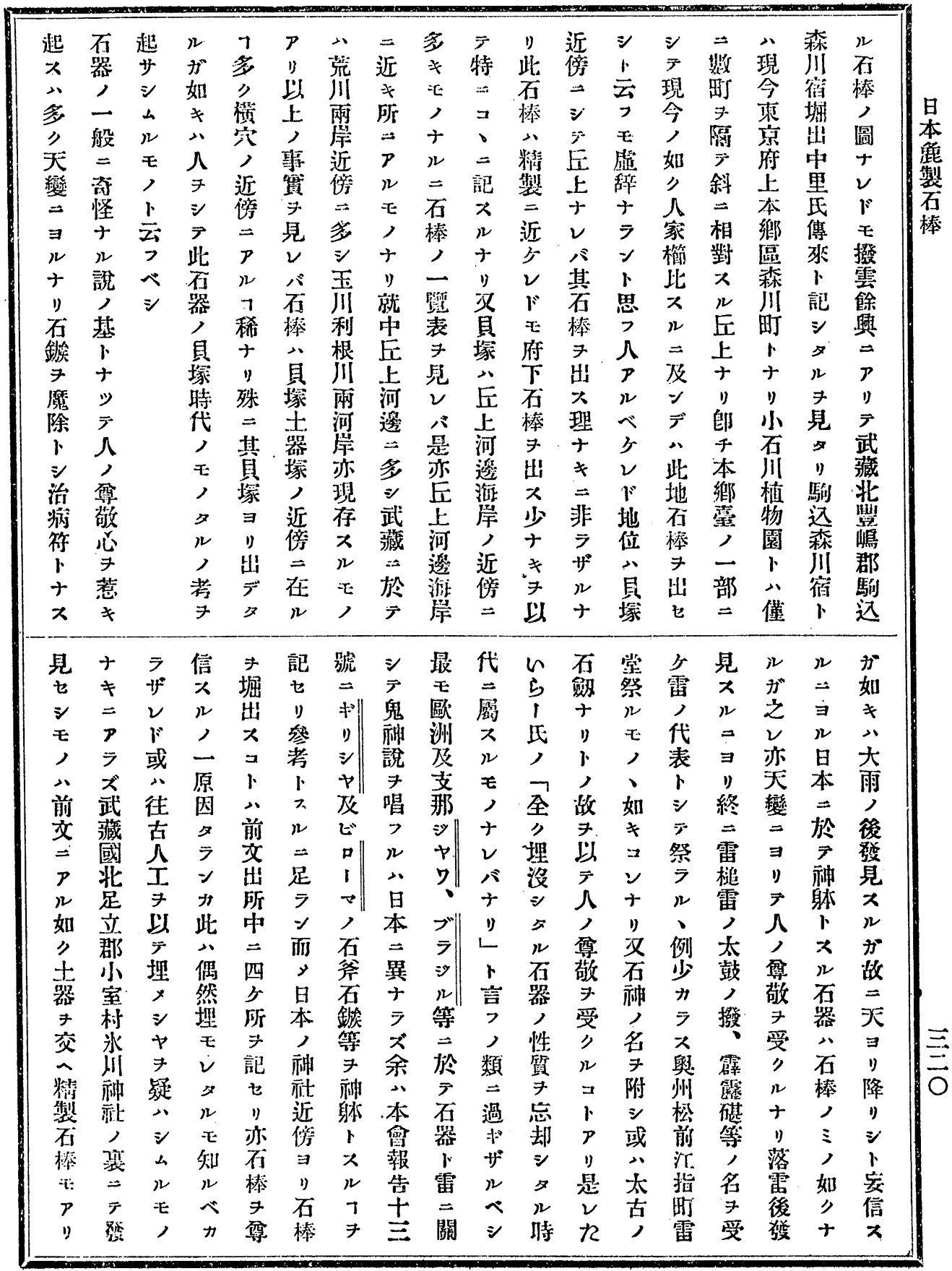




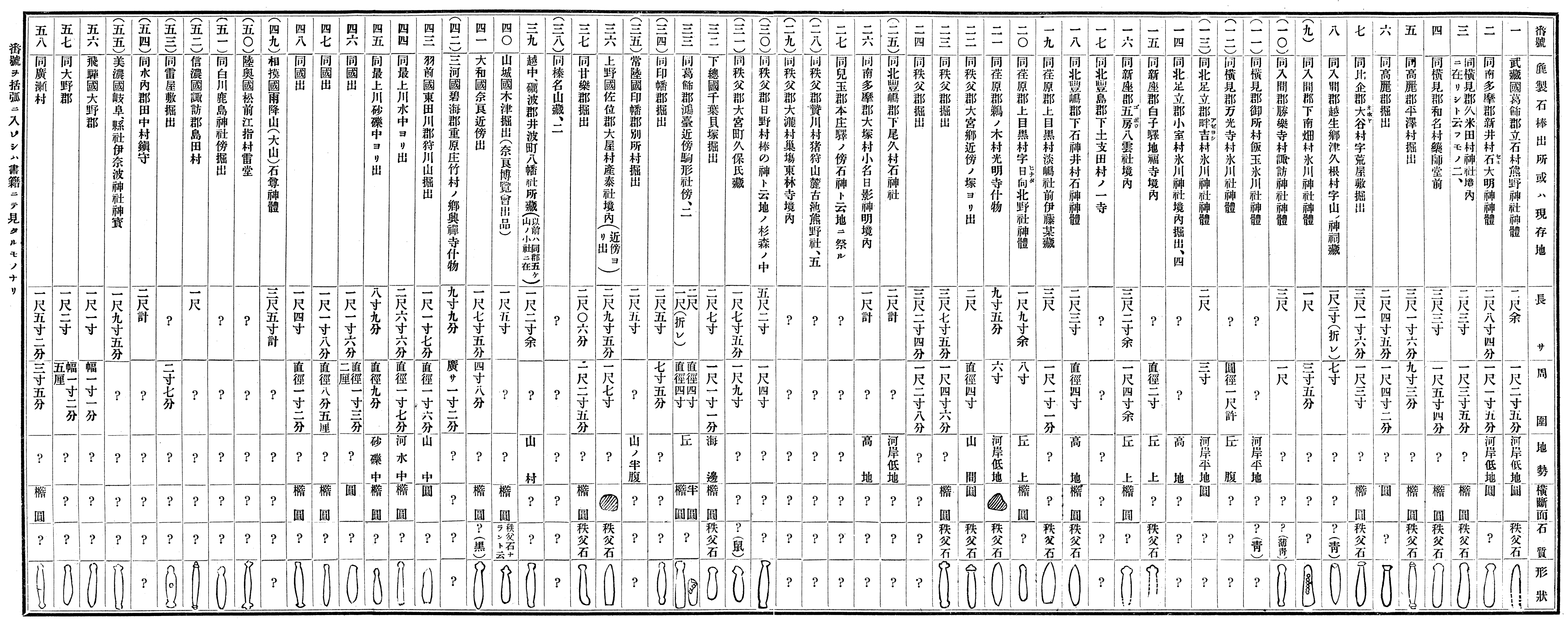


月九年 十二治明

日

本

鹿

製

石

\section{道器小 $2 v$ 塚地七比予}

恐飞附 7 筫 武 7 氏 又支

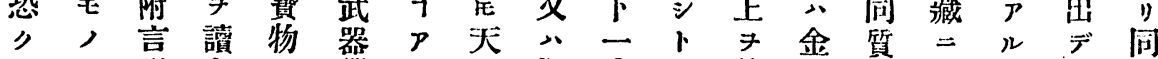

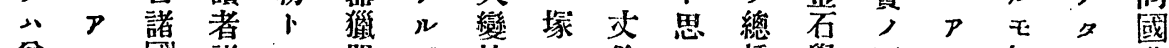
筸》國諸七器が地 $\exists$ 餘心括學石ル知》荏

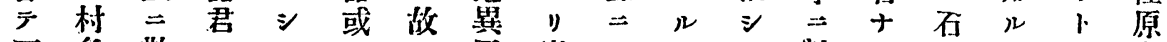

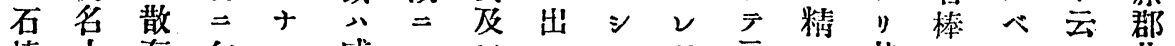
棒小在乞心威

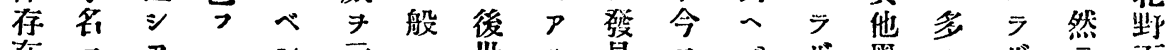

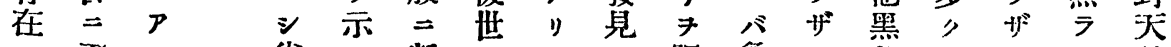
七石少

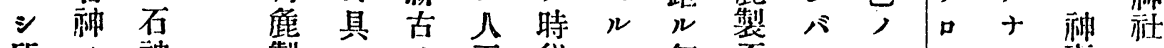
所, 神 ナ名 社

ル,

ベ ミシ

留 テ

妍山神

石ル躱

家王不

, 棒

霨アナ

$=$ " $\overline{7}$

携 是ザ

製 $、$ 工代 $P$ 们石一七

石七云二, 》年棒々,

棒 $シ>\exists$ 差数前入識多

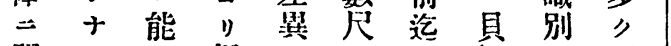

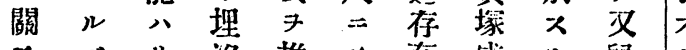

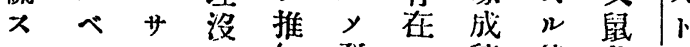

心》ル人知發七皘能色二

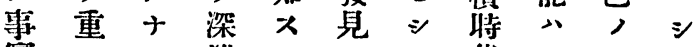

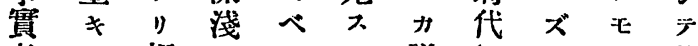

考モ輕 キキル詳既

工等 ル

謨, キ左 $=\boldsymbol{P}=$

, 彼

八 モ在似》ラ 製

飞板

, 傍

報祭ノ ス 具大作

リ碑

儗 $\exists$

式 "

$=$ 出

石 シ

嫩

可

埋 神

4.

儿像

)

古 共

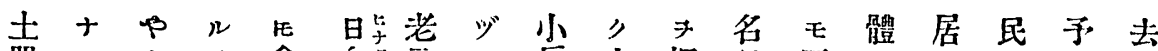

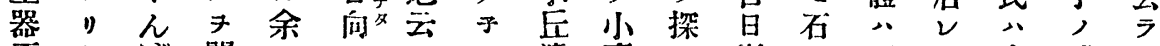

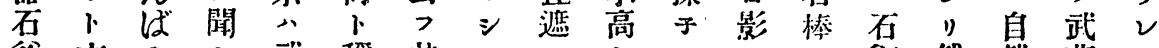

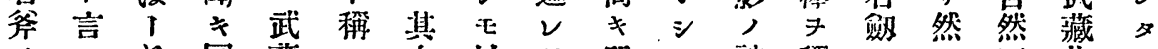

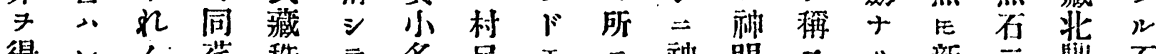

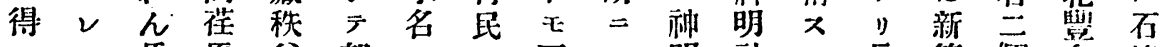

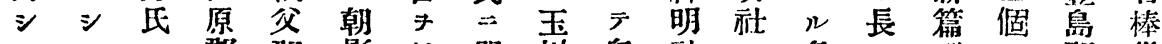

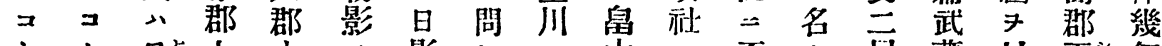

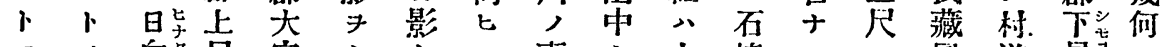
ア 7 向目宮十卡

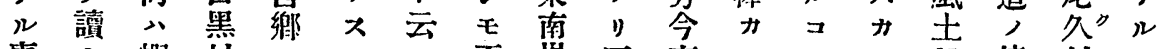

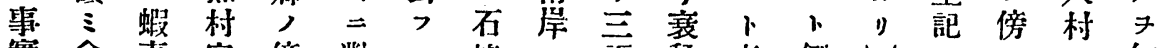

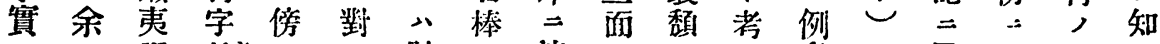
二方語 日忘一

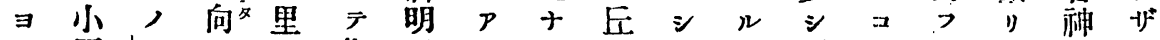
三 $レ$ 石

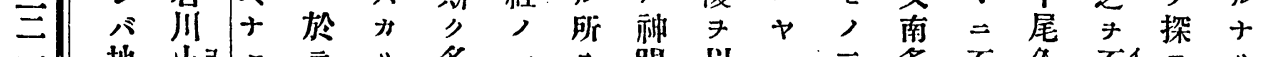

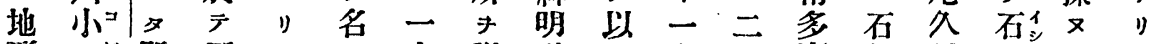

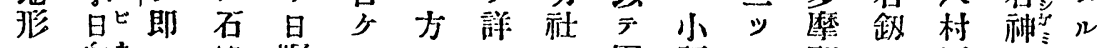

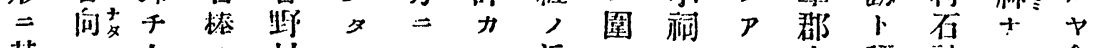

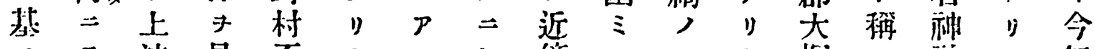

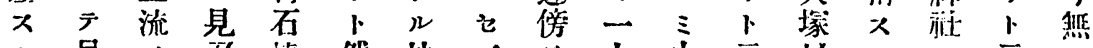

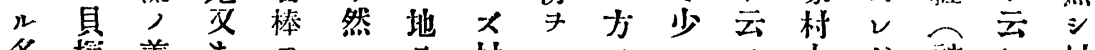

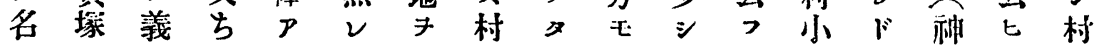




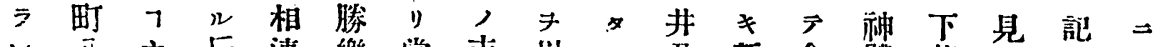

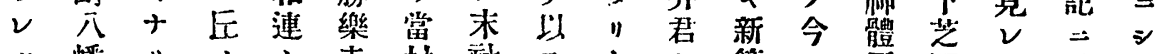

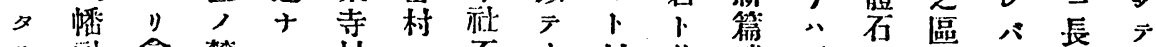

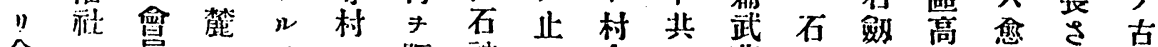

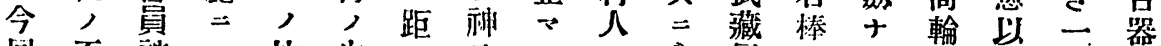

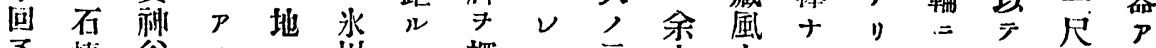

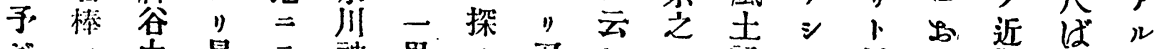

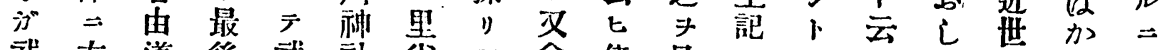

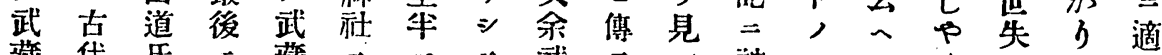

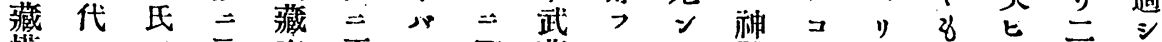

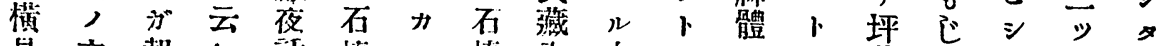

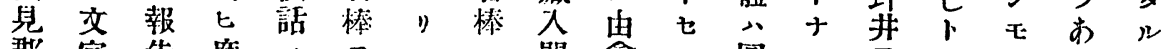

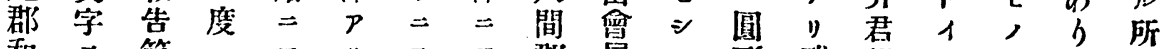
和 7 第 名彫公石 2 此表

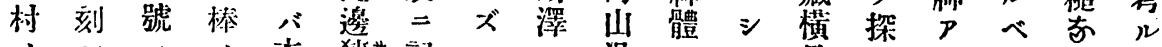

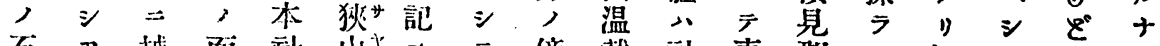

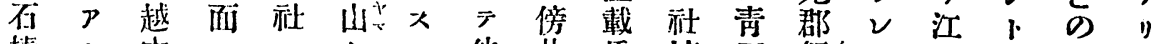
禁

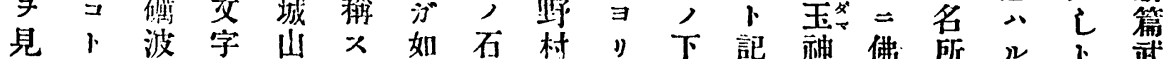
シ 7 郡 7 ト

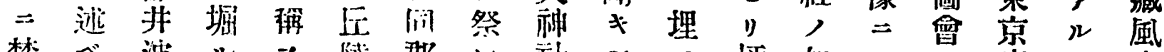

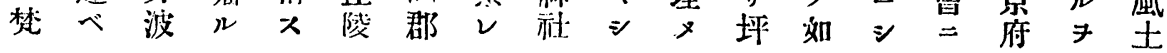

月日所䦌 卯續 䥊 日扶 丙本司野大㚛一於桑考史

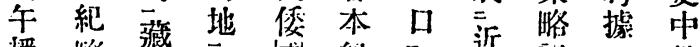

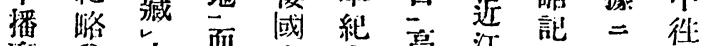

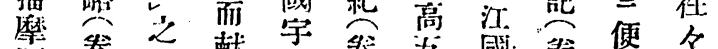

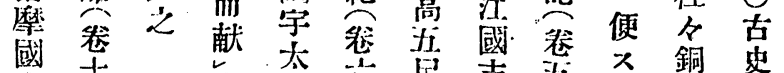

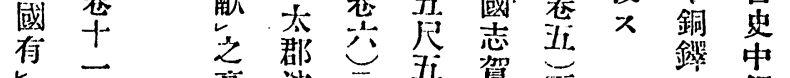

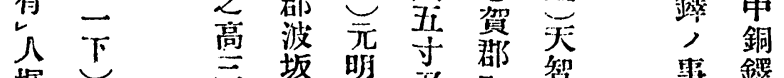

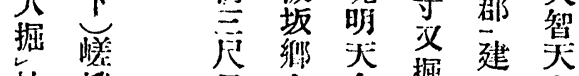

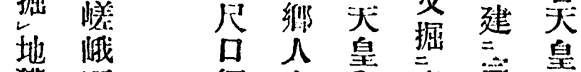

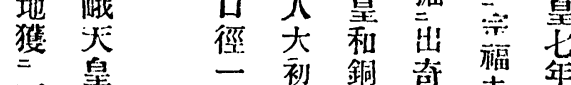

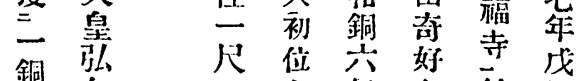
銓仁羅上年白始辰 釷士制村西不命西

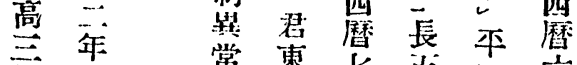
危西常東

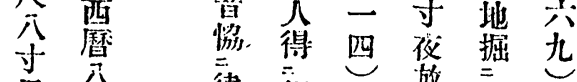
口公 律铜积笠

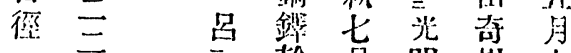

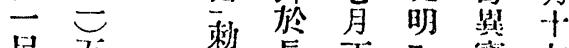

量 鏍

7 ?

載 事

大

ル

著

P

》

左

$=$ 搅

少

鈔

崩辽

示头

W
リの者代二字

飞文 乙注字 テ

々 $尹$ 畫中字

ᄂ 惹十,

小”ド刻

記, 尉, メ

七 三 刻 10

”武 七併之

然藏 n 訅 後

$\nu$ 夜者

萿アべ管

子 $\Rightarrow$ 心 徒

ㄱ $7 \Rightarrow$,

来上知 $P$ 所

世

るの ザザ

7 塧 $\nu$ L H

信よ バ ド デ

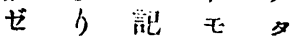

㖣仙 シ 他心

ルる

+8 䓝古, 